\section{ENGINEERING CHANGE NOTICE}

1. ECN 643241

Proj.

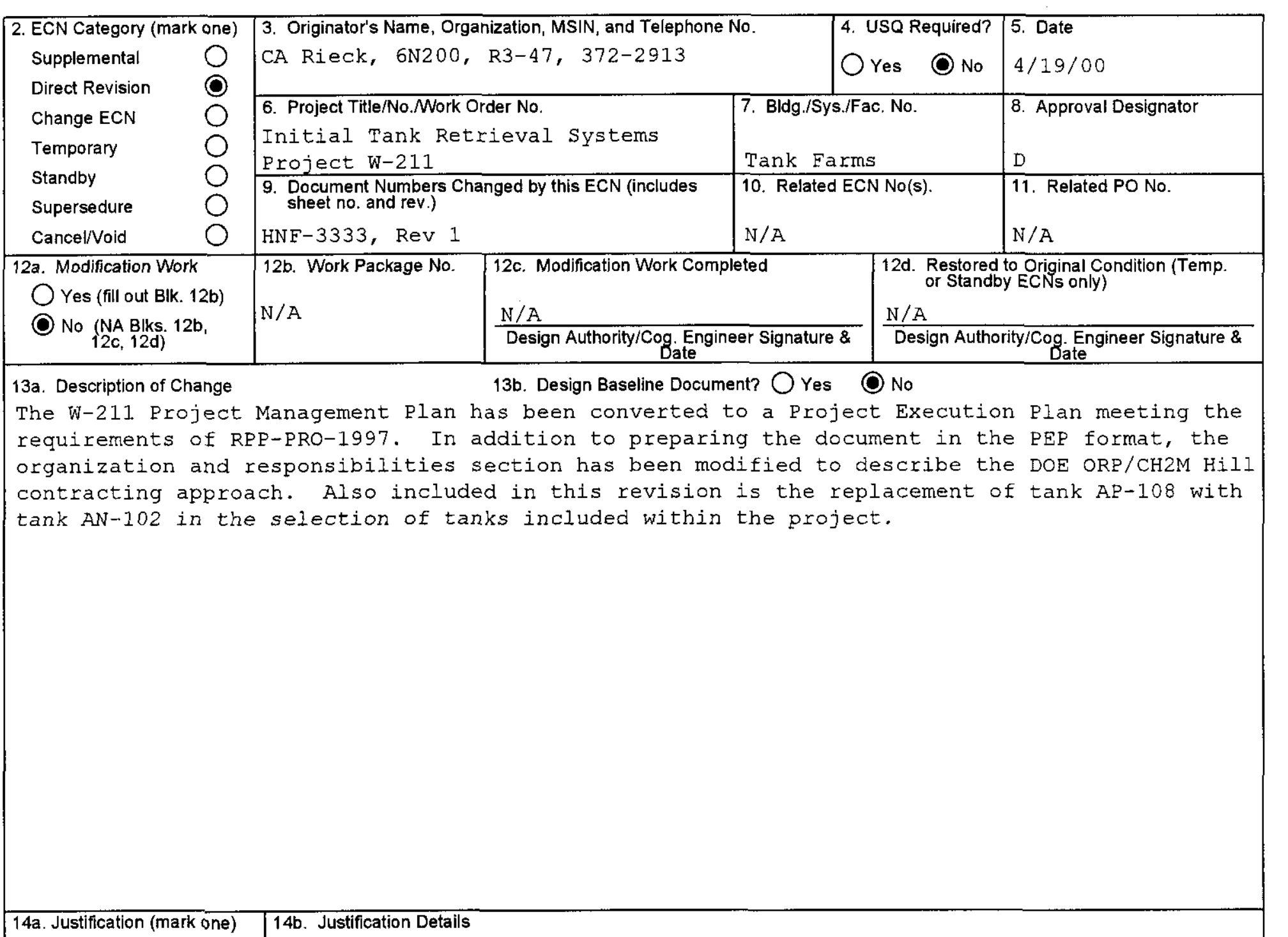

\begin{tabular}{ll|l|l|l}
\hline 14a. Justification (mark one) & 14b. Justification Details \\
Criteria Change & $\mathrm{O}$ & RPP-PRO-1997 requires replacement of PMPs with PEPs that address the 24 \\
Design Improvement & $\bigcirc$ & PEP elements. The replacement of AP-108 with AN-102 was directed by DOE \\
Environmental & $\bigcirc$ & in the ORP fiscal year 2000 Work Authorization and documented in w-211 \\
Facility Deactivation & $\bigcirc$ & change request CR-046. \\
As-Found & $\bigcirc$ & \\
Facilitate Const. & $\bigcirc$ & \\
Const. Error/Omission & $\bigcirc$ & \\
Design Error/Omission & $\bigcirc$ &
\end{tabular}

15. Distribution (include name, MSIN, and no. of copies)

Project Files R1-29

JE Van Beek R3-47

JJ Davis H6-60

CB Bryan R2-58

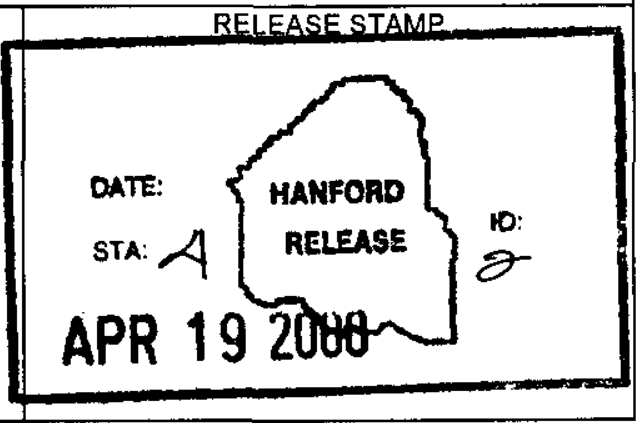


ENGINEERING CHANGE NOTICE

16. Design Verification

Required

17. Cost Impact

(1)

Y Yes

O No

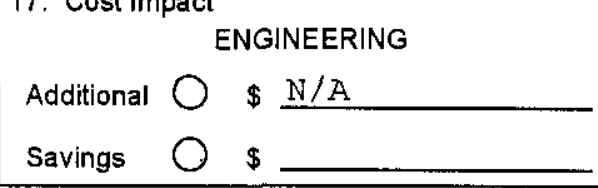

Additional

CONSTRUCTION

\begin{tabular}{l|l} 
Page 2 of 2 & 2 \\
\hline
\end{tabular}

18. Schedule Impact (days)

19. Change Impact Review: Indicate the related documents (other than the engineering documents identified on Side 1) that will be affected by the change described in Block 13. Enter the affected document number in Block 20.

$\begin{array}{llll}\text { SDD/DD } & \square & \text { Seismic/Stress Analysis } & \square \\ \text { Functional Design Criteria } & \square & \text { Stress/Design Report } & \square \\ \text { Operating Specification } & \square & \text { Interface Control Drawing } & \square \\ \text { Criticality Specification } & \square & \text { Calibration Procedure } & \square \\ \text { Conceptual Design Report } & \square & \text { Installation Procedure } & \square \\ \text { Equipment Spec. } & \square & \text { Maintenance Procedure } & \square \\ \text { Const. Spec. } & \square & \text { Engineering Procedure } & \square \\ \text { Procurement Spec. } & \square & \text { Operating Instruction } & \square \\ \text { Vendor Information } & \square & \text { Operating Procedure } & \square \\ \text { OM Manual } & \square & \text { Operational Safety Requirement } & \square \\ \text { FSAR/SAR } & \square & \text { IEFD Drawing } & \square \\ \text { Safety Equipment List } & \square & \text { Cell Arrangement Drawing } & \square \\ \text { Radiation Work Permit } & \square & \text { Essential Material Specification } & \square \\ \text { Environmental Impact Statement } & \square & \text { Fac. Proc. Samp. Schedule } & \square \\ \text { Environmental Report } & \square & \text { Inspection Plan } \\ \text { Environmental Permit } & \square & \text { Inventory Adjustment Request } & \square\end{array}$

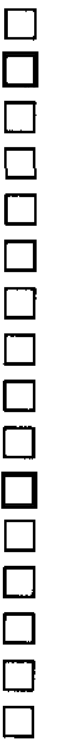

Tank Calibration Manual Health Physics Procedure Spares Multiple Unit Listing Test Procedures/Specification Component Index ASME Coded Item Human Factor Consideration Computer Software Electric Circuit Schedule ICRS Procedure

Process Control Manual/Plan Process Flow Chart Purchase Requisition Tickler File

20. Other Affected Documents: (NOTE: Documents listed below will not be revised by this ECN.) Signatures below indicate that the signing organization has been notified of other affected documents listed below.

$\mathrm{N} / \mathrm{A}$

\section{Approvals}

Signature

Design Authority

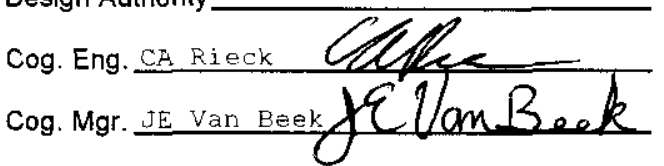

QA

Safety

Environ.

Other

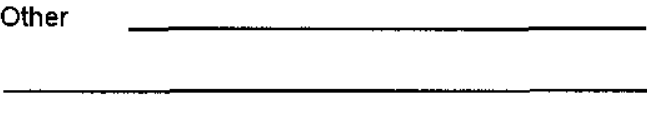

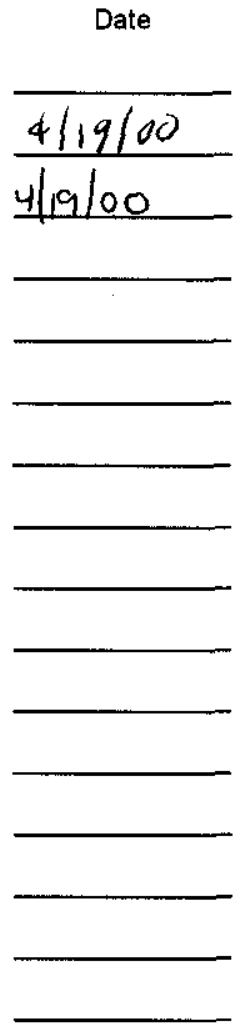

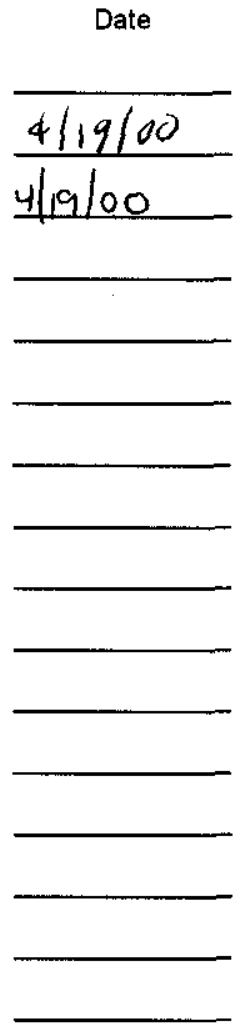

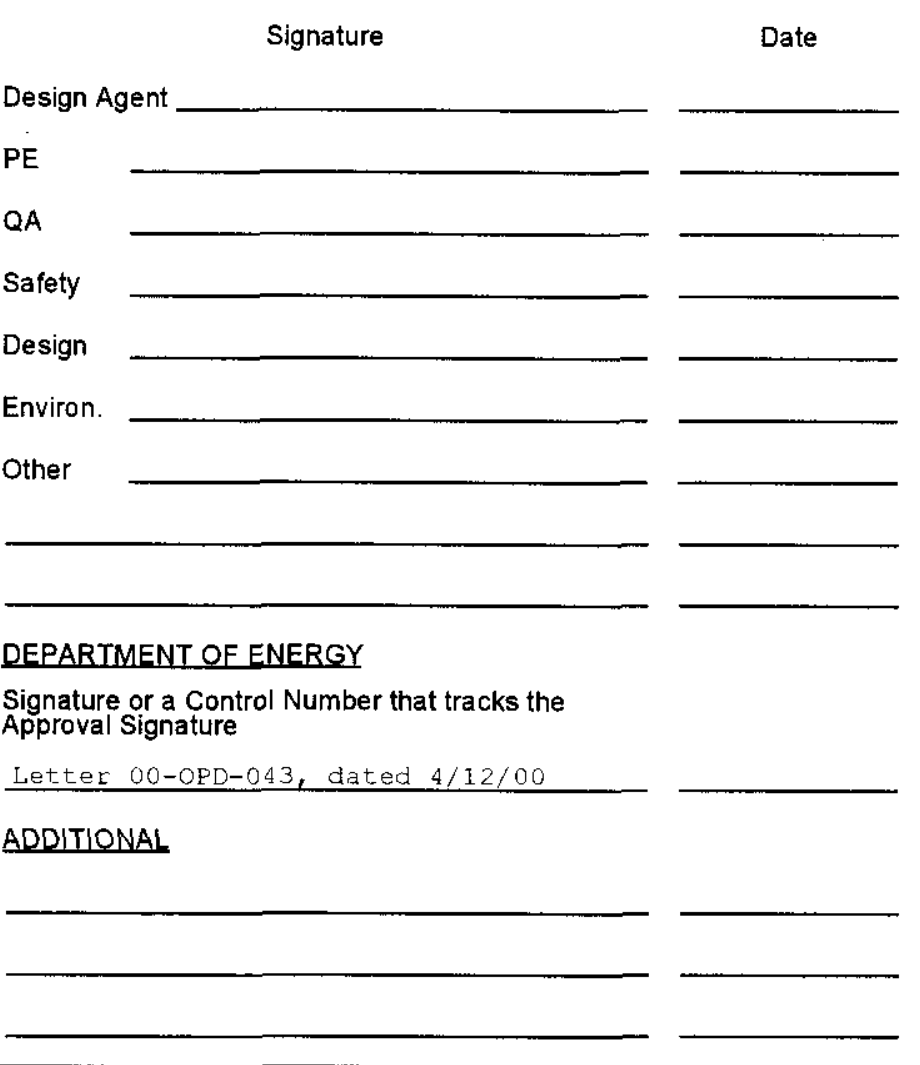




\title{
Project Execution Plan for Project W-211 Initial Tank Retrieval Systems
}

\author{
JE Van Beek \\ CH2M Hill Hanford Group, Inc \\ Richland, WA 99352 \\ U.S. Department of Energy Contract DE-AC06-96RL13200
EDT/ECN: $643241 \quad$ UC: 2030
Org Code: 7C100 Charge Code: 102070
B\&R Code: $39 \mathrm{EW} 02 \mathrm{~J} 10 \quad$ Total Pages: 29

Key Words: Project Execution Plan, Project Management Plan, Project $\mathrm{W}-211$ Initial Tank Retrieval Systems

Abstract: This Project Execution Plan documents the methodology for managing Project $\mathrm{w}-211$.

TRADEMARK DISCLAIMER. Reference herein to any specific commercial product, process, or service by trade name, trademark, manufacturer, or otherwise, does not necessarily constitute or imply its endorsement, recommendation, or favoring by the United States Government or any agency thereof or its contractors or subcontractors.

Printed in the United States of America. To obtain copies of this document, contact: Document Control Services, P.O. Box 950, Mailstop H6-08, Richland WA 99352, Phone (509) 372-2420; Fax (509) 376-4989.
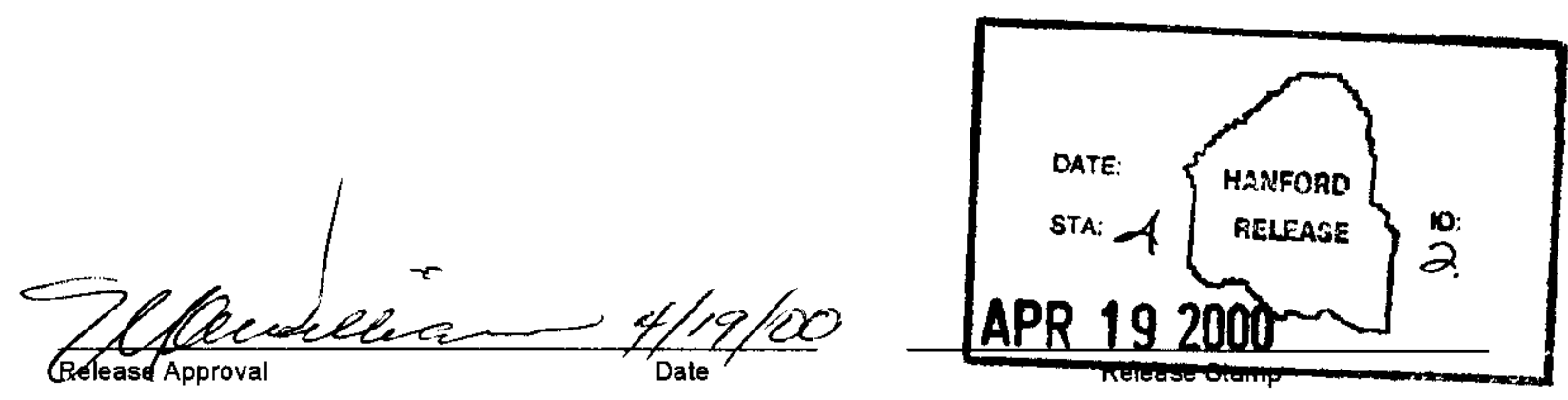

Approved For Public Release 


\section{RECORD OF REVISION}

(1) Document Number
HNE-3333, Rev 2

(2) Title

Project Execution Plan for Project $W-211$, "Initial Tank Retrieval Systems"

\section{Change Control Record}

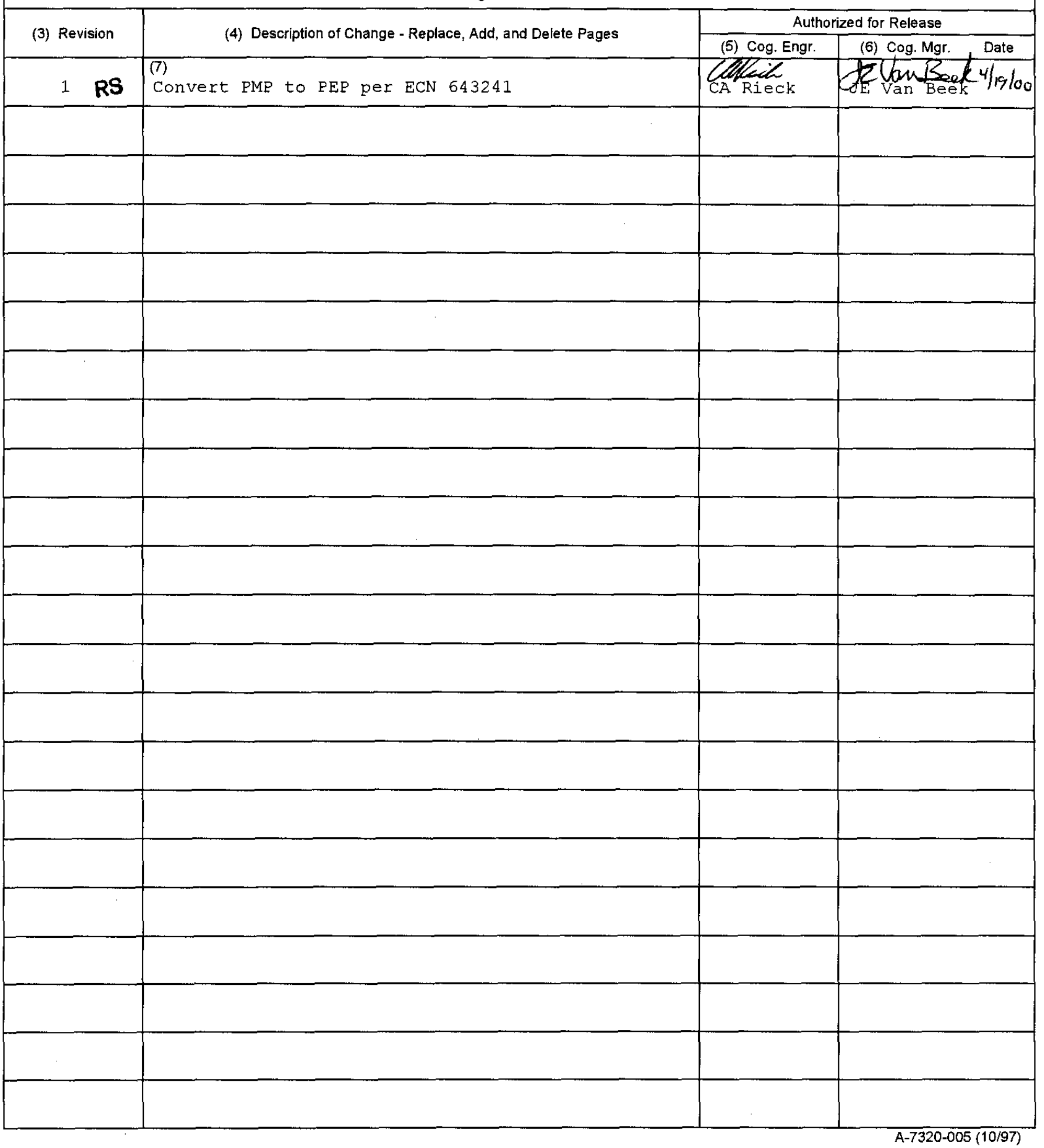


HNF-3333, Rev. 2

\section{PROJECT EXECUTION PLAN}

for

PROJECT W-211

\section{"INITIAL TANK RETRIEVAL SYSTEMS"}

\section{Approvals:}

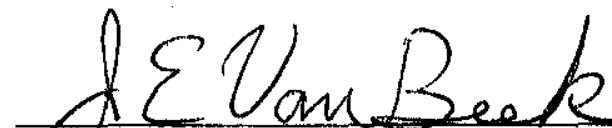

project Manager, CH2M HILL Hanford Group, Inc

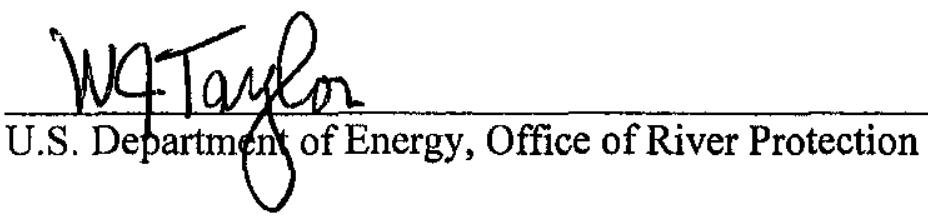




\section{TABLE OF CONTENTS}

1.0 SUMMARY NEED DOCUMENTATION

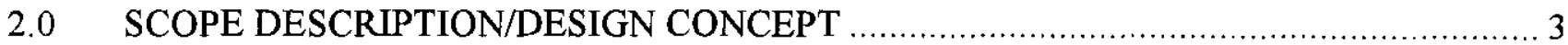

3.0 OVERALL EXECUTION STRATEGY (ORGANIZATION, RESPONSIBILITIES) .......... 4

3.1 U.S. DEPARTMENT OF ENERGY, OFFICE OF RIVER PROTECTION ............... 4

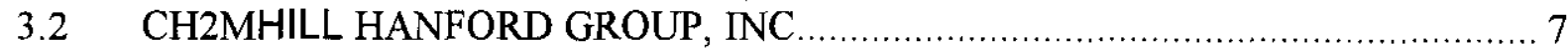

3.3 ARCHITECT ENGINEER/CONSTRUCTION MANAGER _.............................. 9

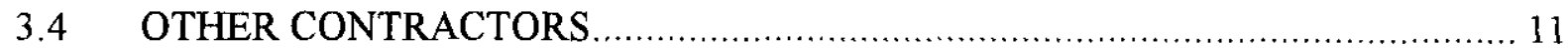

4.0 PROCUREMENT AND CONTRACTING APPROACH …..................................... 11

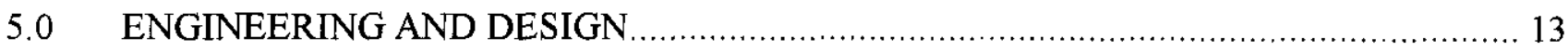

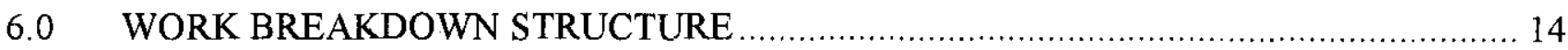

7.0 PERFORMANCE BASELINE DEFINITION AND CONTROL ….............................. 14

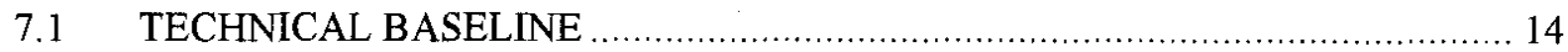

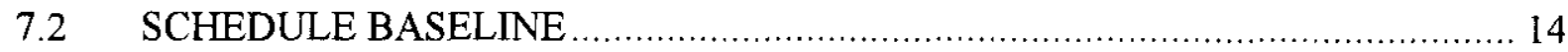

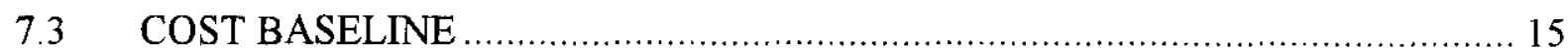

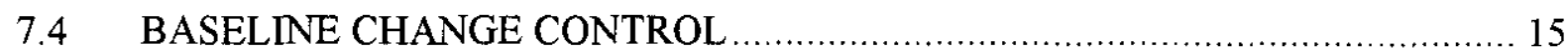

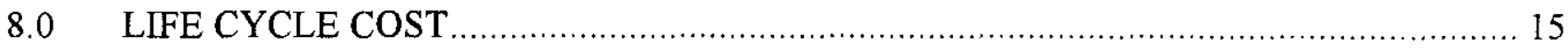

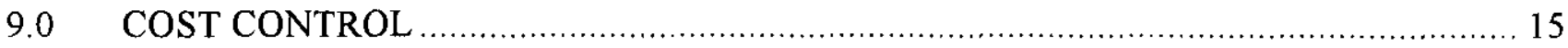

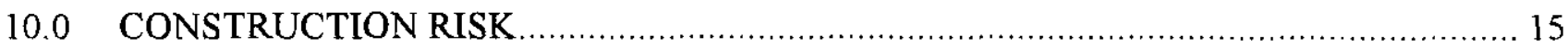

11.0 PERFORMANCE MEASUREMENT, REPORTING, AND FORECASTING …............. 15

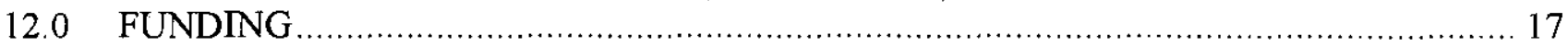

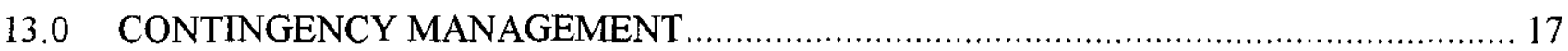

14.0 SITE DEVELOPMENT/TEMPORARY FACILITY AND SERVICES PLAN …............. 17

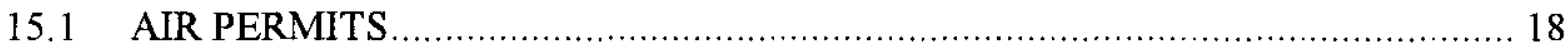

15.2 RCRA AND DANGEROUS WASTE REGULATIONS …….......................... 18

15.3 NATIONAL ENVIRONMENTAL POLICY ACT …...................................... 18

16.0 INSPECTION, TEST, EVALUATION, TURNOVER/ACCEPTANCE AND STARTUP .. 18

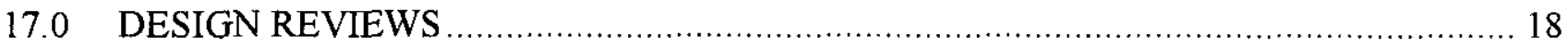

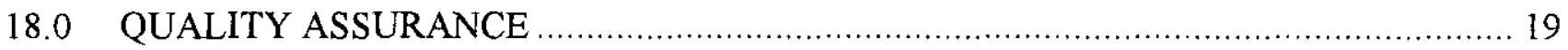

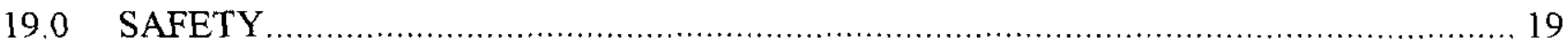

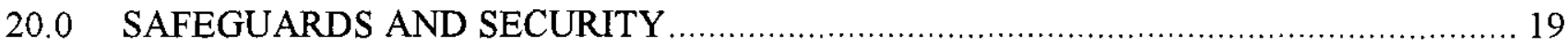

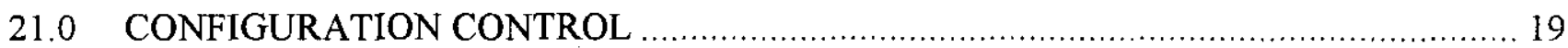

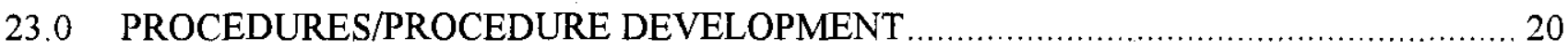

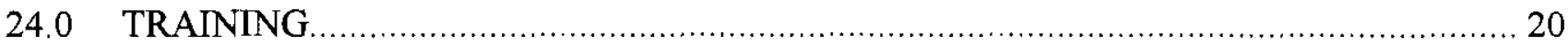

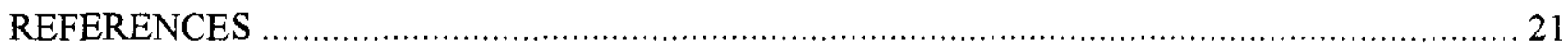

Attachment A …

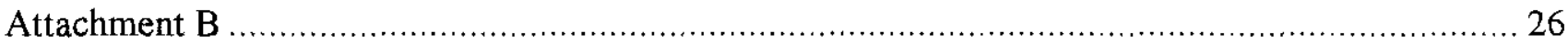




\section{0}

SUMMARY NEED DOCUMENTATION

Project W-211, Initial Tank Retrieval Systems (ITRS), is a fiscal year 1994 Major Systems Acquisition that will provide systems for retrieval of radioactive wastes from selected double-shell tanks (DST). The contents of these tanks are a combination of supernatant liquids and settled solids. To retrieve waste from the tanks, it is first necessary to mix the liquid and solids prior to transferring the slurry to alternative storage or treatment facilities. The ITRS will provide systems to mobilize the settled solids and transfer the wastes out of the tanks. In so doing, ITRS provides feed for the future waste treatment plant, allows for consolidation of tank solids to manage space within existing DST storage capacity, and supports continued safe storage of tank waste.

The ITRS scope has been revised to include waste retrieval systems for tanks AP-102, AP-104, AN-102, AN-103, AN-104, AN-105, AY-102, AZ-102, and SY-102. This current tank selection and sequence provides retrieval systems supporting the River Protection Project (RPP) Waste Treatment Facility and sustains the ability to provide final remediation of several watch list DSTs via treatment. The ITRS is configured to support changing program needs, as constrained by available budget, by maintaining the flexibility for exchanging tanks requiring mixer pump-based retrieval systems and shifting the retrieval sequence. Preliminary design was configured such that an adequate basis exists for initiating Title II design of a mixer pump-based retrieval system for any DST.

This Project Execution Plan (PEP), derived from the predecessor Project Management Plan, documents the methodology for managing the ITRS, formalizes organizational responsibilities and interfaces, and identifies project requirements such as change control, design verification, systems engineering, and human factors engineering.

\subsection{SCOPE DESCRIPTION/DESIGN CONCEPT}

The ITRS scope of work includes the design, procurement, and installation of the following items for tanks AP-102, AP-104, AN-102, AN-103, AN-104, AN-105, AY-102, AZ-102, and SY-102:

- Mixer pumps for sludge mobilization

- Pump for transferring the waste out of the tanks

- Operator station that include functions to monitor, alarm, and control the retrieval system

- Instrumentation required to support operation of the retrieval system, including instrumentation that must be replaced to withstand the mixer pump forces

- Interface with existing instrumentation that is critical to the mixing or transfer process

- Equipment and containers for removal and eventual burial of existing in-tank components

- Utilities for retrieval operations (electrical power, water, telecommunications, etc.) 
- Site preparation and tank modifications for the installation of equipment

- In-line or in-tank dilution capability to bring the waste properties into compliance with transfer line specifications

- Flush capability to both the transfer pump and transfer piping

- A camera system to monitor the retrieval operation

\subsection{OVERALL EXECUTION STRATEGY (ORGANIZATION, RESPONSIBILITIES)}

This section of the PMP focuses on defining the ITRS execution strategy, including project organization, participant roles and responsibilities. Major participants in Project W-211 include the U.S. Department of Energy (DOE), Office of River Protection (ORP), CH2MHILL Hanford Group, Inc. (CHG), and other on and offsite contractors. The $\mathrm{W}-211$ project team is comprised of a number of companies, of which $\mathrm{CHG}$ is the prime, hereby referred to as the Managing Contractor (MC).

Contractual relationships and responsibilities established between DOE and the MC are identified in the U.S. Department of Energy Contract DE-AC06-99RL14047. The contract administration approach entails partnering with the MC to achieve mutually beneficial results.

The key organizational relationships for ITRS are shown in the organization chart on the following page. Only primary members of the project team are depicted in the organization chart, although additional management levels are discussed in the remainder of Section 3.0. Responsibilities are summarized for the major project organizations. The methods of performance for ITRS products are identified in Table 1.

\subsection{U.S. DEPARTMENT OF ENERGY, OFFICE OF RIVER PROTECTION}

Coordinating the activities of Hanford Site prime contractors to accomplish site missions is the responsibility of ORP. Key ORP responsibilities directly influencing construction projects include:

- $\quad$ Preparing and submitting budget requests to HQ supporting Hanford's mission.

- $\quad$ Approving construction related documentation listed in RPP-PRO-1997.

- $\quad$ Proactively interacting with stakeholders.

- Maintaining an appropriate level of project knowledge to assess compliance and to be an informed advocate for construction project activities.

- $\quad$ Supporting the HQ critical decision process.

Authority for contractual direction to the MC is limited to the ORP Contracting Officer (CO) and designated Contracting Officer Representatives (COR). The Operations Program Division (OPD) Director is assigned COR responsibilities for OPD sponsored projects, including Project W-211. 
HNF-3333, Rev. 2

\section{FUNCTIONAL ORGANIZATION CHART PROJECT W-211 \\ INITIAL TANK RETRIEVAL SYSTEMS}

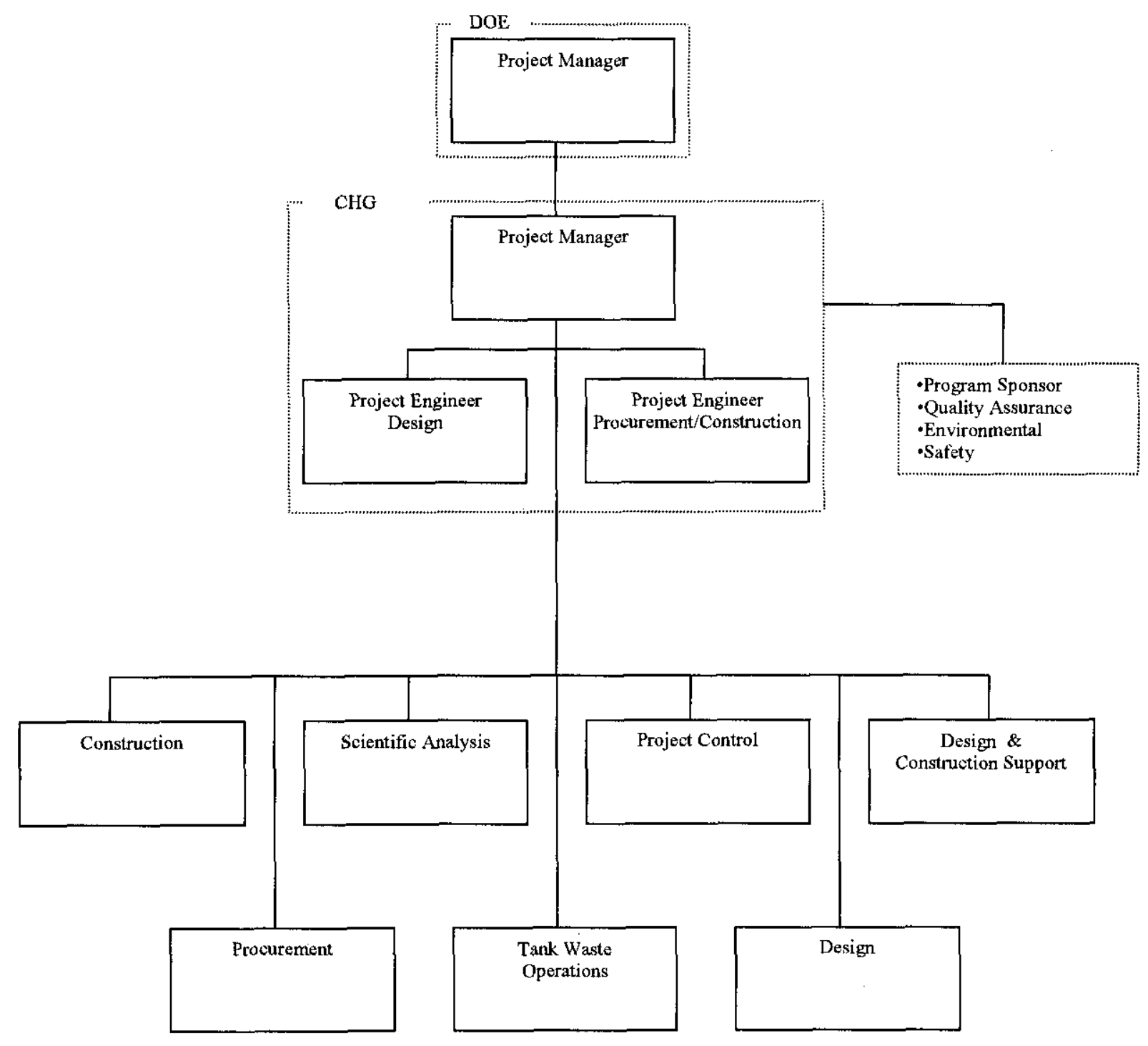


CORs are empowered to act as an authorized representative of the $\mathrm{CO}$ for specified functions. The $\mathrm{CO} / \mathrm{COR}$ shall be fully responsible for providing technical and/or administrative direction to the $\mathrm{MC}$, relative to their project or area of responsibility. In addition, the $\mathrm{CO} / \mathrm{COR}$ shall be responsible for the following items:

A. Provide technical oversight to ensure the products and services for which the $\mathrm{CO} / \mathrm{COR}$ is responsible are delivered in accordance with the contract terms and conditions. Through oversight, ORP should ensure the work is being conducted consistent with the established contract and plans, and that applicable requirements (e.g., statutes, laws, DOE Orders, and policies) are being met. Oversight does not include controlling the way the contractor is doing the work. Oversight is conducted through various means, and the methods used depend on the information needed. Much of the information needed to monitor the contractor performance is available through regular reporting mechanisms. Confirmation of this data can be made through periodic meetings and reviews, site visits, one-on-one discussions, observations, appraisals, audits, and walk-throughs.

B. The CO, or duly designated representative, shall accept work completed by the MC.

C. Review invoices, as required.

D. Provide approval of multi-year work plan documentation.

E. Conduct periodic reviews, audits, surveillances, and DOE independent assessments, of the MC to ensure compliance with the terms of the contract, and that the MC's administration of its subcontractors is effective. These reviews, audits, surveillances, and assessments shall be performed against established criteria to determine contractor progress and to identify any factors that may delay performance or adversely affect environmental protection or protection of worker health and safety. Surveillances may include formal reviews or informal observation and review of work activities.

The CO/CORs are assisted in carrying out their duties by the Project W-211 ORP Project Manager. Primary oversight responsibility for Project W-211 has been delegated by the Assistant Manager for Tank Waste Storage \& Retrieval (AMSR) and Operations Program Division (OPD) CORs to the Project W-211 ORP Project Manager.

DOE-HQ, the regulators, and the Defense Nuclear Facility Safety Board may provide additional oversight. The oversight performed by these organizations will be done in coordination with the Cognizant ORP organization.

The Project W-211 ORP Project Manager reports to the Waste Projects Manager within OPD. The Waste Projects Manager reports to the OPD Director who reports directly to the AMSR. 


\subsection{CH2MHILL HANFORD GROUP, INC}

CHG is responsible for planning, managing and executing the RPP, projects, operations, and other activities as described in contract DE-AC-06-99RL14047. As the MC, CHG is responsible and accountable for management of all activities associated with Project W-211. All contractual and other formal communications concerning Project W-211 shall occur between CHG and ORP.

Programmatic sponsorship of Project W-211 is provided within the Project Delivery organization. This sponsoring organization provides programmatic direction defining projects and programmaticrelated operational needs to Project W-211 within Project Delivery and to Tank Waste Operations (TWO). The Vice President, Project Delivery, is responsible for the Project W-211 life cycle and has delegated responsibility to the W-211 CHG Project Manager (PM), including conceptual, Title I, and Title II designs; equipment procurement; construction; Title III engineering; and construction testing. TWO is responsible for system readiness activities and operation of the Project W-211-supplied systems. The Vice President of TWO and the Vice President of Project Delivery report to the CHG President and General Manager. The PM has direct responsibility and accountability for day-to-day management of Project W-211. Key personnel for Project W-211 are identified in RPP-4852, "Project W-211 Organization Chart."

Specific project management and programmatic/operational responsibilities associated with Project W-211 include the following:

\section{Project Management Responsibilities}

A. Provide a dedicated project manager empowered to authorize and direct all work scope associated with project execution by supporting subcontractors, manage authorized project funds/resources, and approve project cost/schedule baselines.

B. Conduct project activities in accordance with the Project W-211 QAPP, HNF-SD-W211QAPP-001. Perform assessments to assess QA program implementation. Participate in the CHG corrective action management program.

C. Develop project planning and baseline documents.

D. Provide contractual direction to the $\mathrm{A} / \mathrm{E}$ and construction management subcontractors for the performance of design, procurement, and construction. Provide the project technical baseline and safety basis for design.

E. Ensure design media is compliant with the project baseline considering safety, quality, operability, maintainability, environmental compliance, and cost effectiveness factors, and provide approval of the design. Involve Engineering, Operations, Safety, Quality Assurance, Environmental Compliance, etc., in project design reviews, as appropriate, and ensure documented closeout of Design Review Team comments.

F. Provide the administration of overall project change control to assure appropriate management of scope, cost, and schedule commitments. 
G. Provide project direction as necessary for coordination and integration among participating subcontractors for project activities, and provide appropriate direction to assure compliance with the project technical baseline and other technical design criteria.

H. Provide for development of project design and construction schedules.

I. Provide project direction to optimize the design in terms of quality, safety, cost, reliability, maintainability, environmental requirements, accuracy, and interface with other RPP projects. Assure compliance with applicable codes, standards, criteria, regulations, and DOE Orders. Assure that design/construction complies with applicable NEPA/safety documentation/permits.

J. Provide design and construction reports as required.

$\mathrm{K}$. Ensure that quality affecting records providing objective evidence that Project W-211 design, procurement, and construction activities comply with governing requirements are maintained, and that documentation/records providing a traceable project history are properly dispositioned for archive at project completion.

L. Assure the preparation, coordination, and approval (as applicable) of all local, state, and federal environmental documents/permits required for the project.

M. Provide copies of project associated correspondence, reports, drawings, specifications, nonconformance reports, plans and schedules, cost estimates, QA records, audits, subcontracts, meeting minutes, test procedures, photographs, etc., to other team members.

N. Provide timely notification of meetings, scheduled acceptance tests, and final inspections to participants and other appropriate parties.

O. Prepare project reviews and reports, and data for budgetary exercises.

P. Assure preparation of fair cost estimates, as required.

Q. Provide appropriate level of oversight for work performed by other contractors.

R. Coordinate construction activities with Engineering, Operations, Safety, Quality Assurance, Environmental Compliance, etc., and perform oversight of construction contractor safety programs with assistance as required from Projects Field Safety Services. Provide immediate notification of accidents, incidents, significant problems, and work stoppages

S. Assure as-built drawings are prepared.

T. Support construction turnover activities performed in preparation of operational readiness.

U. Provide technical support for reviews of the project documentation by off-site agencies to assure prompt and cost-effective resolution of identified issues.

V. Procure long-lead equipment. 
W. Participate in the CHG corrective action management program to comply with RPP-PRO-052, "Corrective Action Management," for project activities.

$X$. Coordinate development of safety analyses, Authorization Basis amendments, environmental documentation, and other related documentation in support of Project W-211.

Other CHG Responsibilities Supporting Project W-211

A. Provide the technical baseline.

B. Provide the Facility Design Authority associated with Project W-211 retrieval systems.

C. Provide operations liaison between user/sponsor and Project W-211 personnel to minimize interface problems, promote integration, and facilitate project execution. Operations liaison personnel will represent TWO interests as they relate to Project W-211 during project reviews, meetings, and other activities. Operations responsibilities also include acceptance of the project's Acceptance for Beneficial Use (ABU) documentation.

D. Provide programmatic, Operations, Safety, Environmental, Quality Assurance, and Health Physics support for Project W-211 design, construction, and testing.

E. Ensure timely exchange of information, data, records, and guidelines for special conditions/requirements that may impact project cost (e.g., radiation levels, security, safety, and escort requirements, etc.) to the PM.

F. Issue excavation and/or core drilling and/or tie-in permits and welding and/or cutting permits as needed to support construction. Prepare and/or approve radiation work procedures required for project construction.

G. Participate and concur with final inspection and acceptance testing, perform operational testing, and accept completed facilities for operation.

H. Develop operator procedures and training of operations personnel for Project W-211 systems.

I. Perform readiness reviews and startup for completed Project W-211 systems and obtain approvals to operate those systems.

\subsection{ARCHITECT ENGINEER/CONSTRUCTION MANAGER}

Project W-21 lutilizes a design agent from the architect/engineer (A/E) pool to perform Title II design and Title III engineering. In addition, Project W-211 will contract with an ORP-approved construction manager (CM) to provide fixed price construction management and In-Farm construction services. 
Primary $\mathrm{AE} / \mathrm{CM}$ responsibilities are as follows:

A. Provide project design, construction, and Title III engineering. Provide cost estimates and scheduling services for project activities described in Letters of Instruction and/or Statements of Work provided by the PM. Ensure that established project quality objectives and technical requirements are mutually understood and can be satisfied.

B. Assure that design meets the applicable laws, standards, regulations, and the Project W-211 technical baseline.

C. Conduct design status meetings, and issue meeting minutes. Participate in the design review and approval process, construction kickoff, and construction progress meetings.

D. Provide onsite construction and construction management for work by offsite construction contractors, as directed by the PM.

E. Develop cost estimates and schedules for Project W-211 design and construction, and prepare updates to these products as required.

F. Provide welding procedures and welder qualification services.

G. Review and approve vendor data submittals, and maintain and distribute record of status.

H. Perform first-line inspection of construction in accordance with the design.

I. Process Engineering Change Notices and Nonconformance Reports. Provide supporting documentation and tracking status.

J. Assure industrial safety, industrial hygiene, environmental, and security requirements are implemented at the construction site.

K. Assure that design and construction activities are performed consistent with an approved Quality Assurance Program. Ensure that quality affecting records providing objective evidence that design and construction activities comply with governing requirements are maintained, and that documentation/records providing a traceable project history are properly turned over to the designated project files depository for archive at project completion.

L. Manage an effective cost and schedule control system for design and construction activities. Provide construction work progress and cost information to the PM on a routine basis in project status reports.

M. Provide construction site safety inspections and surveillances.

N. Prepare as-built drawings. 
O. Purchase material required for construction, with the exception of long-lead equipment, including inspection of in-process and/or completed products to assure compliance with project requirements.

\subsection{OTHER CONTRACTORS}

Technical support shall be contracted by Project W-211 to develop computer modeling capabilities for waste mixing and transport, assessing waste dilution and heating affects, and resolving flammable gas issues.

Offsite contractors provide fabrication of long-lead equipment, and construction of the instrument buildings and caustic supply systems. Offsite contractor responsibilities are as defined in the respective contracts.

\subsection{PROCUREMENT AND CONTRACTING APPROACH}

Table 1 on the following page provides a listing of the organizations responsible for the major elements of the ITRS WBS. Project W-211 will continue to contract with an A/E from the A/E pool for the remaining Title II design effort as well as Title III engineering during construction. Fixed price contractors will be used for construction of caustic supply systems and control building modifications outside the tank farms. Construction within the tank farms will be contracted to an ORP-approved CM.

Commercial and industrial sources will be used to the extent possible for providing the retrieval system components or sub-systems. Advance procurement for the retrieval systems includes, but is not limited to, the following equipment and systems:

- Mixer pumps, transfer pumps, and other miscellaneous pumps

- Control systems

- Boilers for heating dilution fluid

- Burial containers and equipment

- Component removal equipment

- Closed circuit television and thermocouple assemblies

CHG will provide procurement services for the above equipment and systems. Other materials and equipment required for construction will be procured by the construction contractor. 
TABLE 1 - ITRS METHOD OF PERFORMANCE

\begin{tabular}{|c|c|}
\hline WBS ELEMENT & METHOD OF PERFORMANCE \\
\hline 1.1.1 Project Management & $\mathrm{CHG}$ \\
\hline 1.1.2 Value Engineering & $\mathrm{A} / \mathrm{E}$ \\
\hline 1.2.1 CAA Permits & $\mathrm{CHG}$ \\
\hline 1.2.2 RCRA Permits & $\mathrm{CHG}$ \\
\hline 1.2.3 Safety Assessment & Complete \\
\hline 1.2.4 HPT Support & $\mathrm{CHG}$ \\
\hline 1.3.1 Project Definition & Complete \\
\hline 1.3.2 Design and Construction Support & CHG \\
\hline 1.3.3 Configuration Verification & Complete \\
\hline 1.3.4 Site Characterization & Complete \\
\hline 1.3.5 Equipment Development & Complete \\
\hline 1.3.6 PSE & Complete \\
\hline 1.3.7 Permitting Plan & Complete \\
\hline $1.3 .8 \mathrm{EIS}$ & Complete \\
\hline 1.3.9 Conceptual Design & Complete \\
\hline 1.4.1 Title I Design & Complete \\
\hline $\begin{array}{l}\text { 1.5.A.1 through 1.5.J.1 } \\
\text { Retrieval Systems Title II Design }\end{array}$ & $\mathrm{A} / \mathrm{E}$ \\
\hline $\begin{array}{l}\text { 1.5.A.2 through 1.5.J.2 } \\
\text { Retrieval Systems Title III Engineering/Acceptance Inspection }\end{array}$ & $\mathrm{A} / \mathrm{E} / \mathrm{FD}$ \\
\hline $\begin{array}{l}\text { 1.5.A.3 through 1.5.J.3 } \\
\text { Retrieval Systems Advance Procurement }\end{array}$ & Offsite Contractors via CHG Procurement \\
\hline $\begin{array}{l}\text { 1.5.A.4.1 through 1.5.J.4.1 } \\
\text { Retrieval Systems Construction - In-Farm Construction }\end{array}$ & $\mathrm{CM}$ \\
\hline $\begin{array}{l}\text { 1.5.A.4.2 through 1.5.J.4.2 } \\
\text { Retrieval Systems Construction - ICE Building \& Utilities }\end{array}$ & Offsite Contractors \\
\hline $\begin{array}{l}\text { 1.5.A.4.3 through 1.5.J.4.3 } \\
\text { Retrieval Systems Construction - Caustic Supply System }\end{array}$ & Offsite Contractors \\
\hline $\begin{array}{l}\text { 1.5.A.4.4 through 1.5.J.4.4 } \\
\text { Retrieval Systems Construction - Burial }\end{array}$ & CHG \\
\hline $\begin{array}{l}\text { 1.6. A through } 1.6 . \mathrm{J} \\
\text { Startup }\end{array}$ & $\mathrm{CHG}$ \\
\hline
\end{tabular}


Functional Design Criteria (FDC) HNF-SD-W211-FDC-001 provides the Project W-211 technical baseline. The technical baseline established by the FDC has been enhanced by the Title I design report, WHC-SD-W211-TDR-001, Revision 0, Title I Supplement 1, WHC-SD-W211-TDR-001, Revision 0A, and Title I Supplement 2, WHC-SD-W211-TDR-001, Revision 0B. Collectively, these Title I documents define the Project W-211 preliminary design basis, including analysis of generic features sufficient to provide an adequate technical basis for starting Title II design of a mixer pumpbased retrieval system for any DST. The Project W-211 Systems Engineering program is described in HNF-3310, "Systems Engineering Management and Implementation Plan for W-211."

An evaluation of the integration of human factors engineering into the design is provided in PNNL-1 1442, "Human Factors Engineering Evaluation, Project W-211, Initial Tank Retrieval Systems (ITRS), DST 241-SY-102." Findings of this evaluation are applied to each Title II design.

Through the end of 1999, Title II design for SY-102, AP-102, AP-104, and AN-105 retrieval systems were completed. Title II design of AZ-102 and AN-104 were underway, with the design start for AN-102 scheduled for June 2000. A detailed statement of work (SOW) issued to the A/E, defines each design task. In response to the SOW and request for proposal, the A/E prepares a Scope of Facilities (SOF) and Scope of Services (SOS) document supporting a detailed cost proposal for the design. CHG project management reviews the SOF/SOS and cost proposal. If necessary, negotiation of the proposal is accomplished between the $\mathrm{A} / \mathrm{E}$ and $\mathrm{CHG}$ Contracts. After agreement on the proposal, a contract release is issued to the $\mathrm{A} / \mathrm{E}$ defining the final SOF/SOS and cost estimate for the design task.

Prior to commencing each design, the A/E prepares a Technical Data Checklist (TDC) listing the bases documents that control the design effort. The TDC is approved by the A/E and CHG and is placed under configuration control in accordance with RPP-4856, "Project W-211 Configuration Management Implementation Plan."

Throughout the design effort, periodic technical review meetings are conducted with CHG project management and other members of the $\mathrm{CHG}$ design review team as appropriate. In addition to providing status, the review meetings provide a forum for resolving issues as the design progresses. The A/E documents minor variances to the planned design approach as Deviations. Deviations are forwarded to $\mathrm{CHG}$ and monitored throughout the design duration. As determined by agreement between the $\mathrm{A} / \mathrm{E}$ and $\mathrm{CHG}$, significant Deviations are processed as Change Requests in accordance with Section 7.0, "Performance Baseline Definition and Control." Monthly design progress and performance is formally reported by the $\mathrm{A} / \mathrm{E}$ to the $\mathrm{CHG}$ project manager (PM).

Intermediate design reviews are conducted as risk management efforts to help ensure the final product meets the technical requirements and review team expectations. Near the end of Title II design for each of the retrieval systems, the $\mathrm{A} / \mathrm{E}$ performs an independent review and constructibility review of the design media. After completing the $\mathrm{A} / \mathrm{E}$ reviews and comment resolution, the design is submitted to CHG for review as described in Section 17, "Design Reviews." The CHG review team includes members from TWO, Maintenance, Project Delivery, Nuclear Safety, Industrial Safety, Fire Projection, Radiation Protection, Engineering, Environmental, Quality Assurance, and other subject 
matter experts as appropriate. Completed, approved designs are released in the Hanford document control system under configuration control as described in RPP-4856.

Interfaces between Project W-211 design and other project designs or existing facilities are documented in HNF-1507, Interface Document, Project W-211, Initial Tank Retrieval Systems."

In addition to design, the $\mathrm{A} / \mathrm{E}$ provides scheduling and cost estimating services as requested by $\mathrm{CHG}$ project management. These services are described in the W-211 SOW issued to the A/E. Also included in the $\mathrm{A} / \mathrm{E}$ scope of work is Title III engineering during construction. This function includes providing as-built drawings, supporting acceptance testing, reviewing contractor and supplier submittals, developing Engineering Change Notices to support construction, and providing engineering dispositions to Non-Conformance Reports as requested by $\mathrm{CHG}$ project management. Title III engineering is a task included in the SOW issued to the $\mathrm{A} / \mathrm{E}$ and is controlled by contract release in the same manner as discussed above for Title II design.

\subsection{WORK BREAKDOWN STRUCTURE}

The Project Summary Work Breakdown Structure (PSWBS) is included as Attachment B. All work performed on project W-211 shall be planned and controlled in a lower level structure that supports reporting to the PSWBS.

\subsection{PERFORMANCE BASELINE DEFINITION AND CONTROL}

The Project W-211 baselines identified in the following sections are reflective of the completed Title I design; Title II designs for SY-102, AP-102, AP-104, AN-105, and AZ-102; and the latest tank selection and retrieval sequence. Revisions to the baselines below will be accomplished via the Baseline Change Control process and will not result in mandatory revisions to the PEP.

\subsection{TECHNICAL BASELINE}

Functional Design Criteria (FDC) HNF-SD-W211-FDC-001 provides the Project W-211 technical baseline. The technical baseline established by the FDC has been enhanced by the Title I design report, WHC-SD-W211-TDR-001, Revision 0, Title I Supplement 1, WHC-SD-W211-TDR-001, Revision 0A, and Title I Supplement 2, WHC-SD-W211-TDR-001, Revision 0B. Collectively, these Title I documents define the Project W-211 preliminary design basis, including analysis of generic features sufficient to provide an adequate technical basis for starting Title II design of a mixer pumpbased retrieval system for any DST.

\subsection{SCHEDULE BASELINE}

Attachment A includes the upper-level schedule for providing retrieval systems for the tanks within the project scope. Consistent with the Attachment A schedule, milestones established via Performance Incentives and DOE milestones included in the Multi-Year Work Plan provide the ITRS schedule baseline. 


\subsection{COST BASELINE}

The cost baseline for ITRS is shown in Table 2 and is based on the latest tank selection and retrieval sequence, and the June 1999 project estimate reflecting completion of Title II designs for SY-102, AP-102, AP-104, and AN-105 retrieval systems.

\subsection{BASELINE CHANGE CONTROL}

Changes to ITRS baselines are authorized by approval of a change request (CR) in accordance with RPP-IP-0842, Volume VIII, Section 1.1, "Baseline Change Control." Changes below the following thresholds are processed within ITRS. Changes above these thresholds are processed by CHG and DOE change control boards in accordance with the Baseline Change Control Procedure.

- Cost increases requiring more than $10 \%$ of the original total contingency, or any scope change requiring the use of contingency

- Any single increase of more than $\$ 50,000$ to the fiscal year expense budget

- Schedule changes 45 days or more later than DOE designated milestones

- Technical changes adversely impacting another project

- Changes requiring modification of the W-211 Functional Design Criteria

\subsection{LIFE CYCLE COST}

Life cycle costs for Project W-211 are equivalent to the Total Project Cost and are estimated from the beginning of the project definition phase in the early 1990s through project completion at the end of the Operational Test Procedures. The TPC cost baseline for ITRS is shown in Table 2. The latest update to the life cycle cost was performed in June 1999 and is the basis of the Table 2 cost baseline.

\subsection{COST CONTROL}

See Section 11.0 for a discussion of cost control as part of the system for performance measurement, reporting, and forecasting.

\subsection{CONSTRUCTION RISK}

The ITRS Risk Management program, including construction risk, is described in HNF-3310, "Systems Engineering Management and Implementation Plan for W-211." Significant risk events are reported and managed via the W-211 risk list. A detailed risk analysis was conducted as part of the project cost estimate update in June 1999. The detailed risk analysis was focused on construction risks and provided the basis of determining the appropriate level of contingency included in the updated estimate.

\subsection{PERFORMANCE MEASUREMENT, REPORTING, AND FORECASTING}

Project performance will be monitored against the baseline and reported in accordance with ORP requirements. Monthly Management Review Meeting reports are provided to ORP. 
TABLE 2 - COST BASELINE

$(\$ \times 1000)$

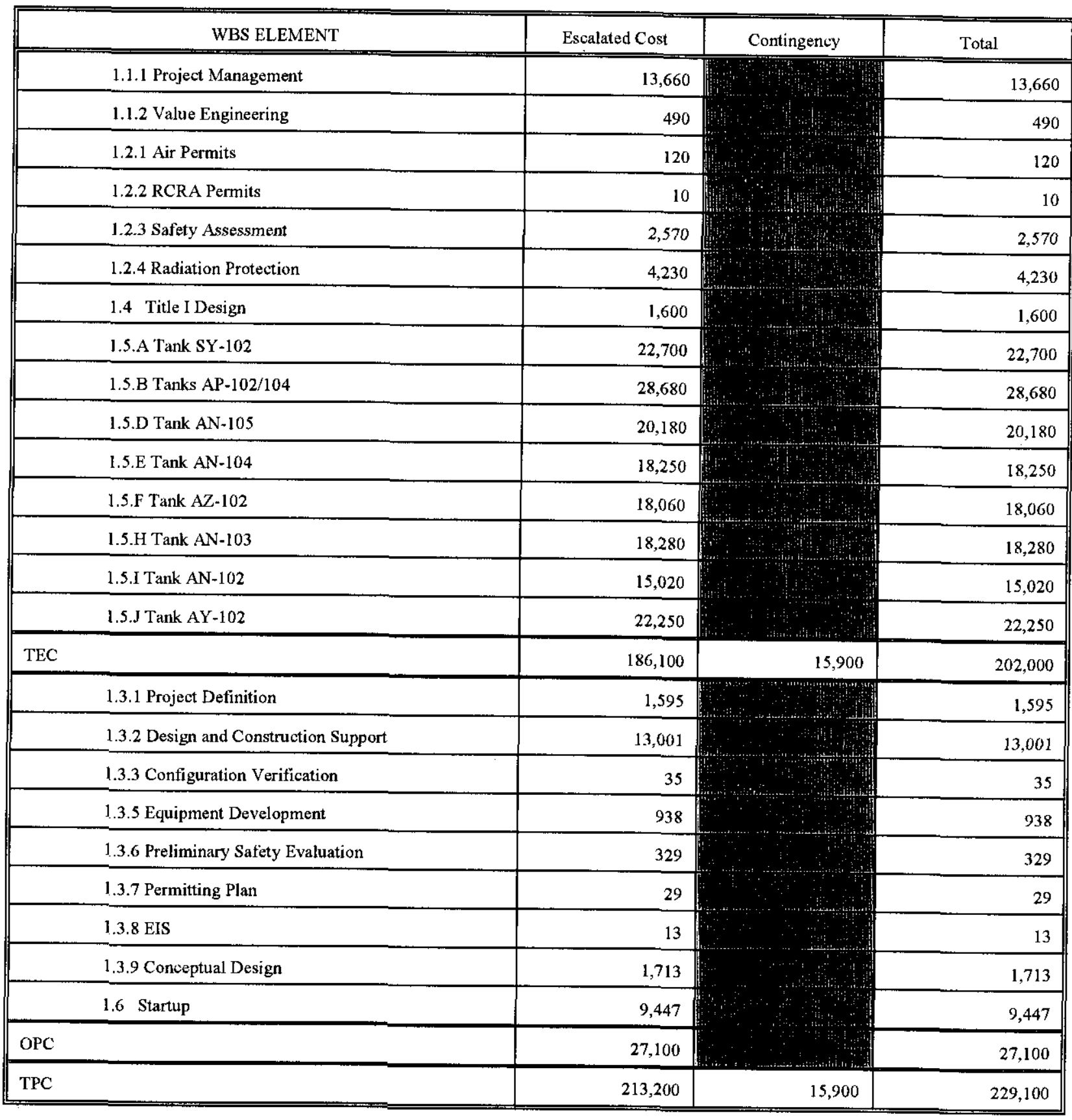


Project planning and performance reporting is accomplished by a combination of the PM, various performing organizations, and Project Controls Specialist (PCS) efforts. The PM has overall responsibility for planning and reporting. Supporting contractors provide monthly status, via the PM, for work in progress.

During schedule development, each performing organization prepares a detailed plan for producing project products. Agreement is reached with the PM on the schedule and the associated resources. The PCS develops task descriptions, durations, and logic based on detailed information from the performing organizations. The PCS is responsible for constructing the schedule from the supplied data.

Each month the performing organizations report progress to the PCS, who reviews the reports and forwards them and earned value data to the PM. Reports are forwarded to ORP in the form of Management Review Meeting reports.

\subsection{FUNDING}

Annual capital funding, consistent with the $\$ 202,000,000$ Total Estimated Cost baseline, is included in the Project Data Sheet provided to Congress as part of the federal budgeting process. Amounts of the requested W-211 budget authority is determined through the Multi-Year Work Plan process based on a project schedule supporting the Waste Feed Delivery Program. Budget-year funding for ITRS is reviewed by the annual Project Validation conducted by DOE-HQ or DOE-ORP.

Expense funding to support capital project work is determined on an annual basis through the MYWP process and is included in the overall budget request. Annual expense funding is provided to Project W-211 via a Sub-Operations Directive. Monthly reports are provided to the Project Delivery including cost performance information. Formal review of expense funding for Project $\mathrm{W}-211$ is performed by the RPP at mid-year. Forecasted expense funding underruns are returned to the Program for other uses. Increases in annual expense funding are obtained via change request.

\subsection{CONTINGENCY MANAGEMENT}

Cost contingency is managed within the change control process discussed in Section 7.4 above. The CHG PM maintains a log of all change requests authorizing the use of contingency. The W-211 schedule does not include contingency allowances, although RPP does include schedule contingency between the end of W-211 construction/startup and the planned operational date as depicted on the Mission Summary schedule.

\subsection{SITE DEVELOPMENT/TEMPORARY FACILITY AND SERVICES PLAN}

Not applicable to Project W-211 that is modifying existing tank farm facilities. 
Environmental statutes applicable to ITRS include the Clean Air Act, the Resource Conservation and Recovery Act (RCRA), and the National Environmental Policy Act (NEPA). The following sections describe the ITRS environmental compliance actions.

\subsection{AIR PERMITS}

Approvals from the Washington State Department of Health, Washington State Department of Ecology, and the U.S. Environmental Protection Agency, via Notice of Construction letters, will be obtained before construction of the retrieval systems.

\subsection{RCRA AND DANGEROUS WASTE REGULATIONS}

The current DST Part A Dangerous Waste Permit Application does not require any revision for ITRS. ITRS activities before 2001 are covered under Interim Status. ITRS will be included in the DST Part B Permit scheduled for issuance in 2001.

\subsection{NATIONAL ENVIRONMENTAL POLICY ACT}

Mixer pump-based retrieval of waste from DSTs is covered in the Hanford Defense Waste Environmental Impact Statement (HDW-EIS). DST waste retrieval is additionally covered in the TWRS-EIS and the related Record of Decision dated February 20, 1997.

\subsection{INSPECTION, TEST, EVALUATION, TURNOVER/ACCEPTANCE AND STARTUP}

Acceptance inspection (AI) for the Government is provided by Fluor Hanford as described in AI plans prepared for each of the construction packages for each retrieval system. ITRS test and evaluation requirements are described in the HNF-4855, "Project W-211 Test and Evaluation Plan."

Near the completion of construction the project will demonstrate system compliance with the design by conducting Acceptance Test Procedures. After successful completion of ATPs, the system is turned over to Operations for demonstration, with Project expense funds, that the system satisfies functional requirements via Operational Test Procedures (OTP). At successful completion of OTPs, Operations is presented with Acceptance of Beneficial Use (ABU) documentation as evidence of a completed retrieval system ready for startup and assessment of readiness. Operations acceptance of the $\mathrm{ABU}$ package completes the project activities associated with the retrieval system and terminates expenditures of project capital and expense funds for that system. Operations acceptance of ABU documentation for the final retrieval system completes the project.

\subsection{DESIGN REVIEWS}

Design verification via independent review will be performed by the Design Agent for all design media and subsequent changes. In addition, Title II designs will be reviewed at the "Issue for Review" stage by a team comprised of operations, safety, quality assurance, environmental, engineering, program, and project representatives. Additional review activities are discussed in Section 5.0 above. 
Project W-211 quality assurance requirements are described in the HNF-SD-W211-QAPP-001, "Project Specific Quality Assurance Plan, Project W-211, Initial Tank Retrieval Systems."

\subsection{SAFETY}

\subsection{CONSTRUCTION SAFETY}

Construction shall be conducted in accordance with RPP-PRO-078, "Subcontractor Safety \& Health Management," and RPP-MP-003, "Integrated Environmental, Safety and Health Management System Plan (ISMS)." For construction activity involving radiological work the concept of ALARA shall be incorporated. A life-cycle management approach to radiation dose, contamination control and radiological waste minimization shall be implemented. Construction shall be conducted in compliance with HSRCM-1, "Hanford Site Radiological Control Manual."

Additional procedures that control construction activities include: DOE-RL-92-36, "Hanford Site Hoisting and Rigging Manual," and DOE-RL-SOD-INST-L\&T-001, "Hanford Site Lockout/Tagout Program."

\subsection{FACILITY SAFETY ANALYSIS}

A Preliminary Safety Evaluation (PSE) was prepared for Project W-211 during the conceptual phase of the project. The PSE identified and evaluated the risks and hazards associated with retrieval of DST waste and provided the safety basis for development of Title I and Title II designs.

HNF-SD-W211-PSAD-001, "Safety Assessment for Initial Tank Retrieval Systems, Project W-211," was accepted by DOE on April 2, 1998 as a basis for proceeding with ITRS construction with the understanding the Unreviewed Safety Question (USQ) process will be followed prior to construction to verify Project W-211 construction activities can be conducted within the existing tank farms authorization basis $(\mathrm{AB})$.

Prior to operation of Project W-211 systems, an AB amendment package will be prepared by the Project Delivery for the overall waste feed delivery system and receive DOE approval.

\subsection{SAFEGUARDS AND SECURITY}

No special safeguards or security are required for the project. Only normal security requirements for the 200 Areas are imposed.

\subsection{CONFIGURATION CONTROL}

The configuration management system described in HNF-3310, "Systems Engineering Management and Implementation Plan for W-211," is used for ITRS configuration control and serves as the project-specific configuration management plan for ITRS. 
HNF-3333, Rev. 2

\subsection{DOCUMENT AND RECORD MANAGEMENT}

Project documents and records shall be prepared, reviewed, approved, controlled, maintained and retired in accordance with RPP-PRO-232, "Project and Task Document Management," and RPP-4856, "Project W-211 Configuration Management Implementation Plan."

\subsection{PROCEDURES/PROCEDURE DEVELOPMENT}

No project specific procedures are planned for ITRS.

\subsection{TRAINING}

The "Project W-211 Qualification and Training Plan," requires that all Project W-211 personnel meet specific qualification requirements, are trained to applicable procedures, and that records of training and qualification are maintained. The Project W-211 PM and Project Engineers are required to obtain Project Delivery qualification certification. 


\section{REFERENCES}

1. WHC-SD-W211-TDR-001, "Title I Design Summary Report, Initial Tank Retrieval Systems, Project W-211"

2. HNF-SD-W211-FDC-001, "Functional Design Criteria, Project W-211, Initial Tank Retrieval Systems"

3. HNF-SD-W211-QAPP-001, "Quality Assurance Program Plan for Project W-211, Initial Tank Retrieval Systems"

4. HNF-SD-W211-PSAD-001, "Safety Assessment for Initial Tank Retrieval Systems, Project W-211"

5. HNF-1507, "Interface Document, Project W-211, Initial Tank Retrieval Systems"

6. HNF-3310, "Systems Engineering Management and Implementation Plan For Project W-211, Initial Tank Retrieval Systems"

7. RPP-4852, "Project W-211 Organization Chart"

8. RPP-4855, "Project W-211 Test and Evaluation Plan" 
HNF-3333, Rev. 2

Attachment A

Baseline Schedule 


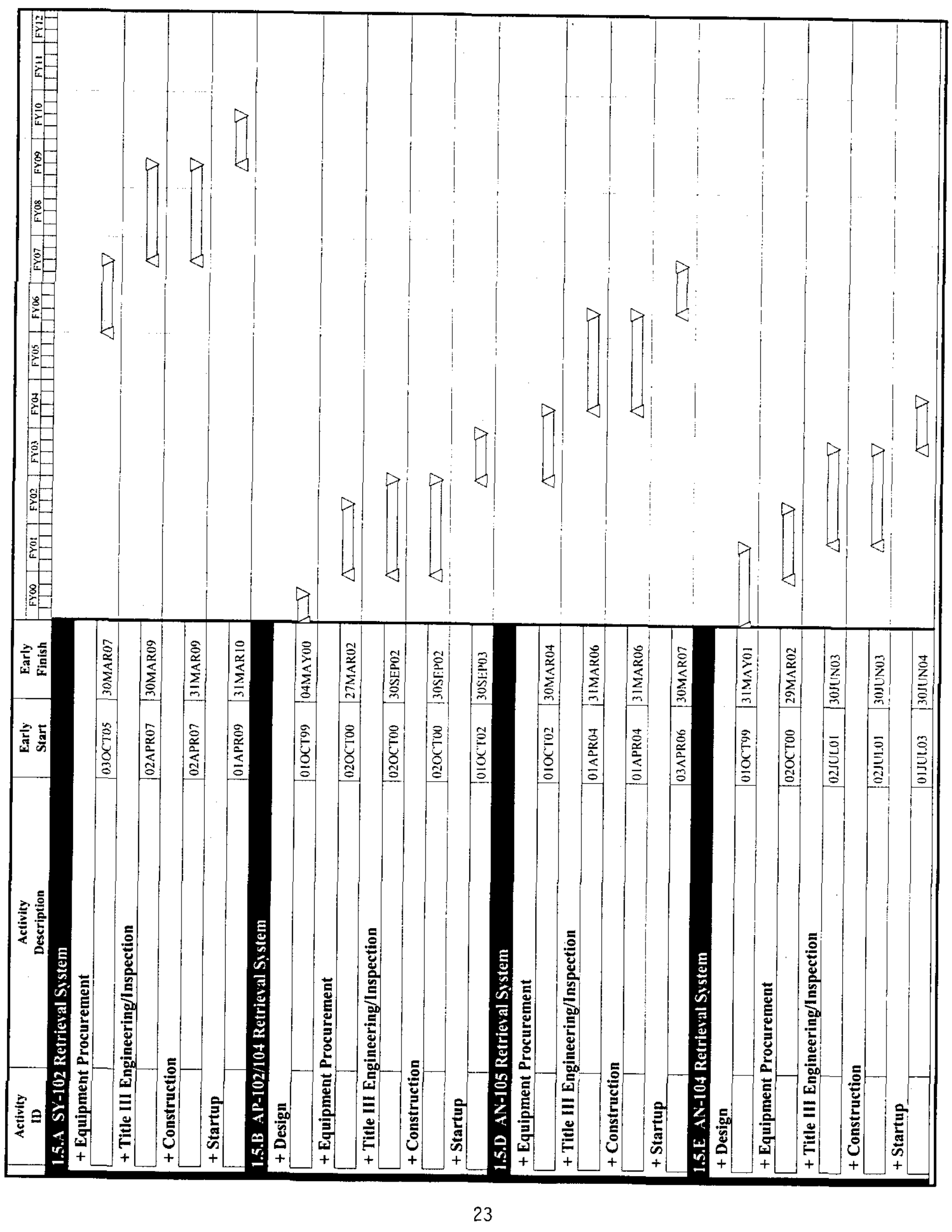




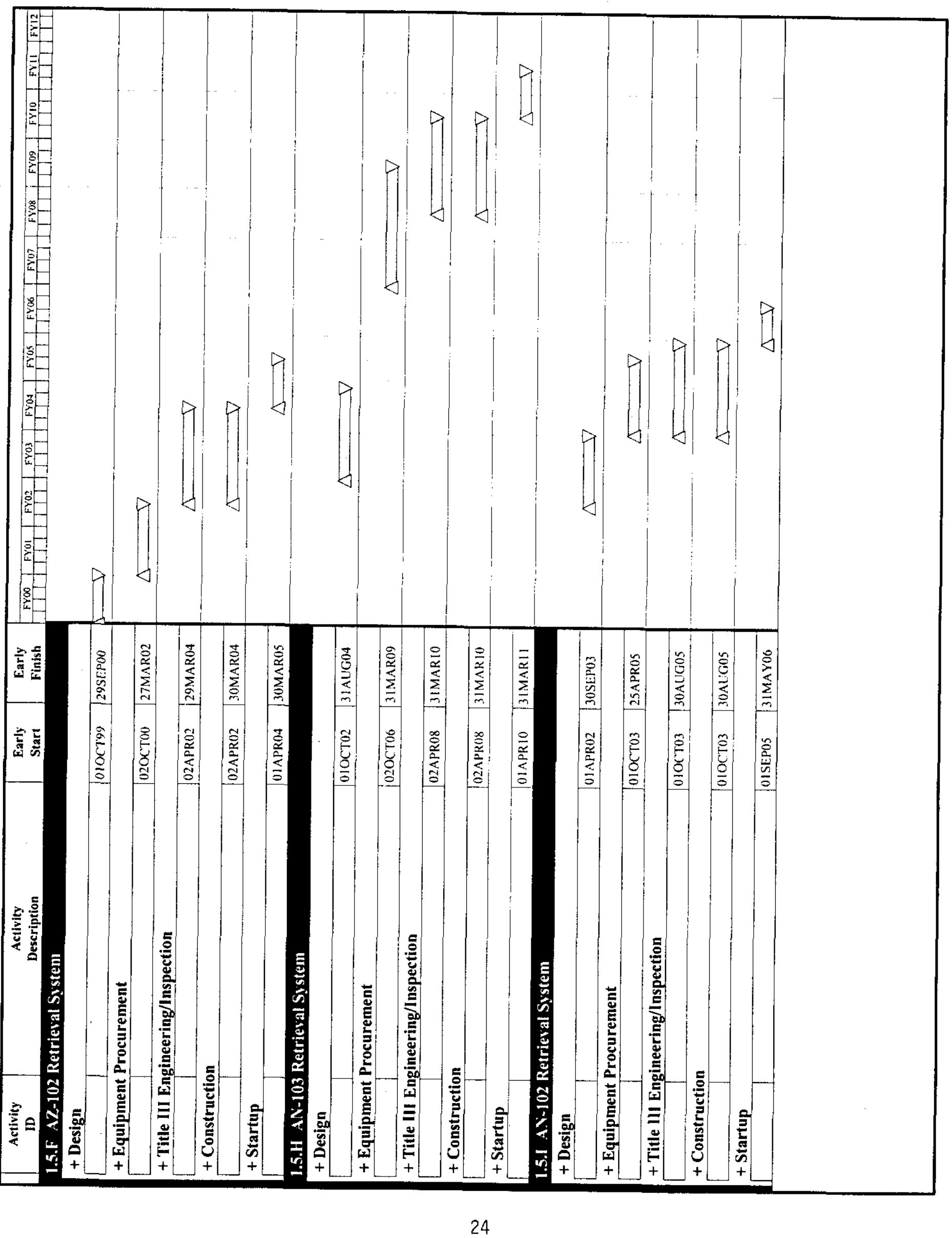


HNF-3333, Rev. 2

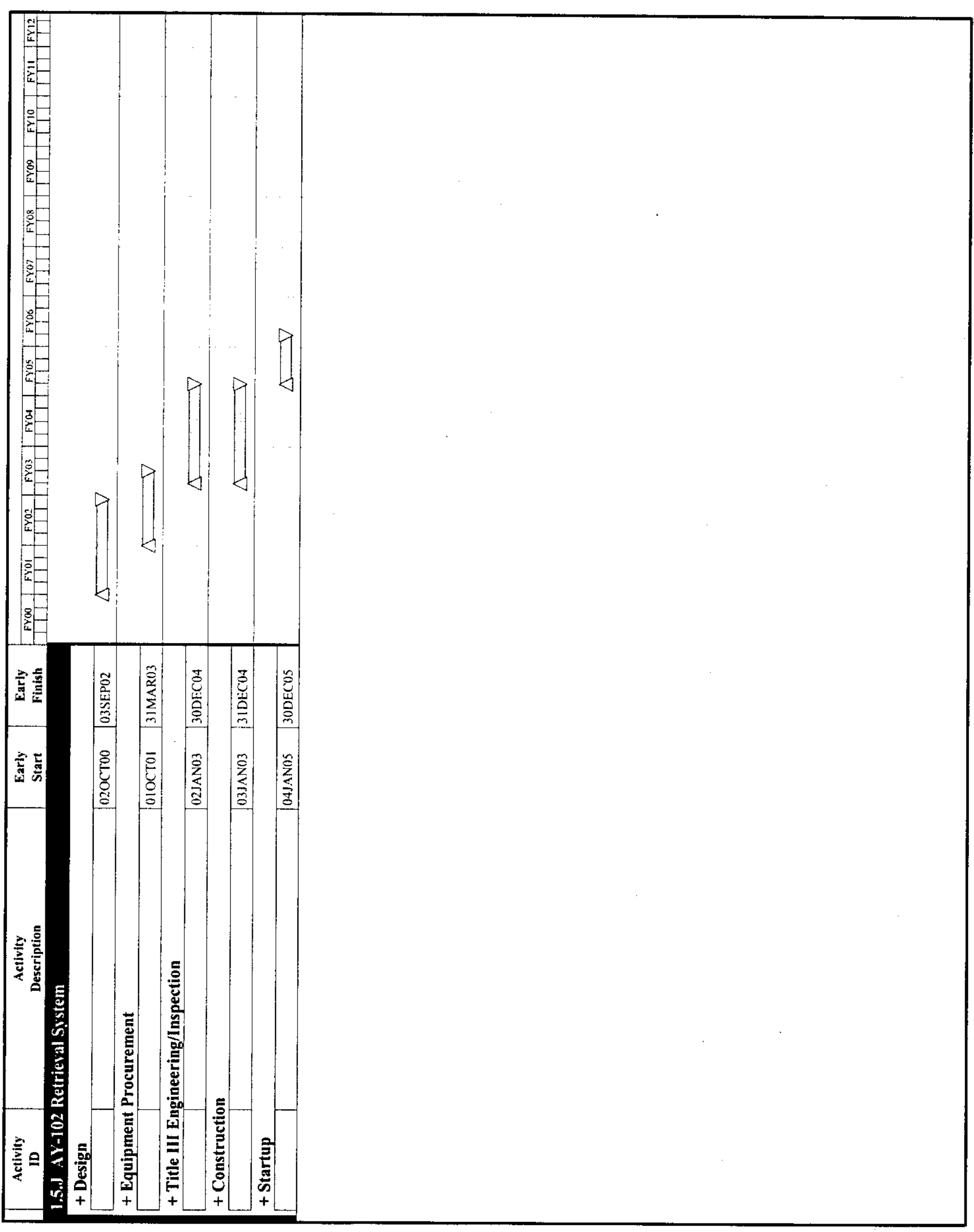


HNF-3333, Rev. 2

Attachment B

Work Breakdown Structure 
HNF-3333, Rev. 2

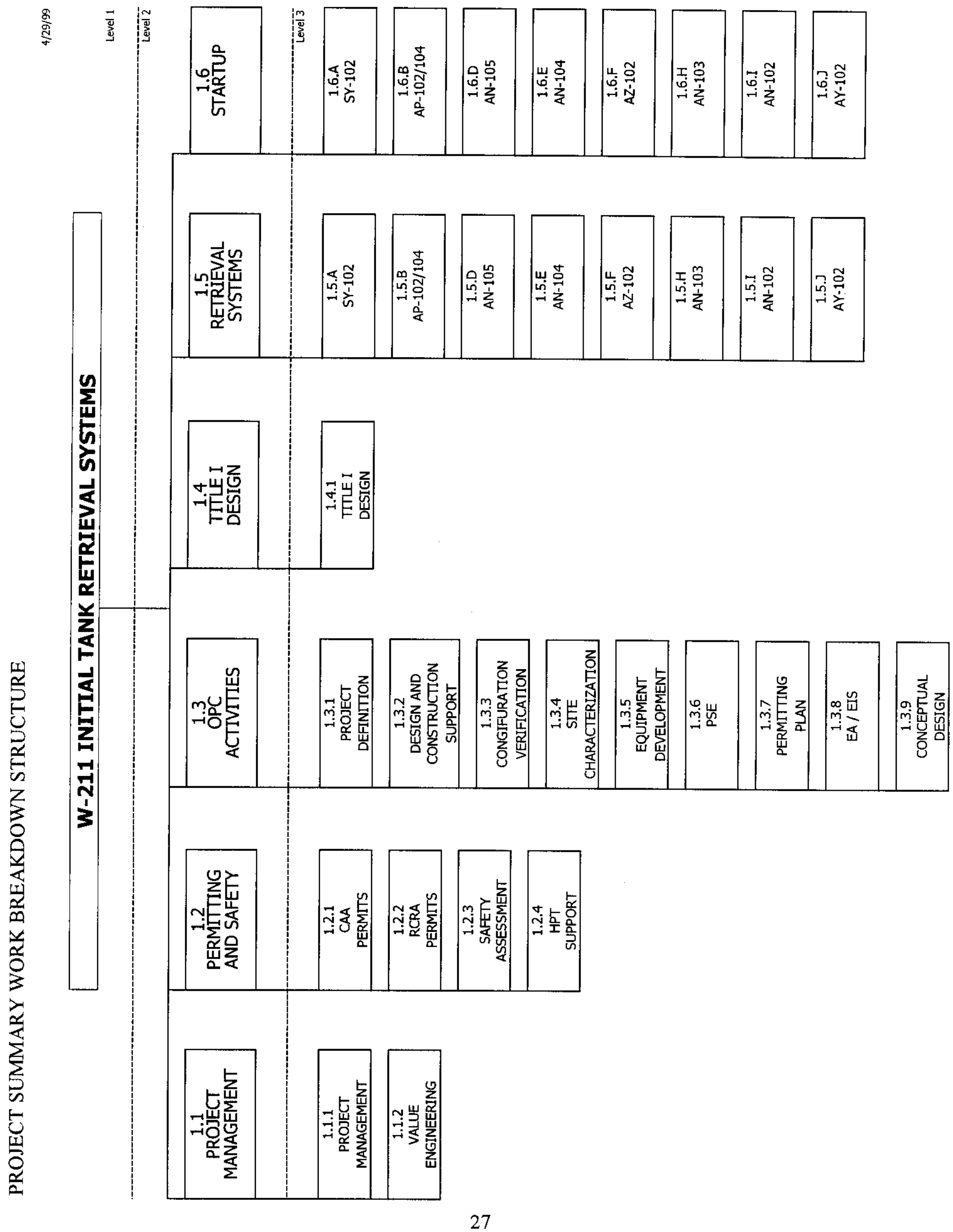

